\title{
Antecedents of Employee Organizational Commitment at Public Sector Organizations in West Sumatra
}

\author{
Mega Asri Zona', Megawati ${ }^{2}$, Arief Maulana ${ }^{3}$ \\ ${ }^{1}$ Dept. of Management, Faculty of Economics, Universitas Negeri Padang, Padang, Indonesia, \\ $\square$ (e-mail) megaasrizona@gmail.com \\ ${ }^{2}$ Dept. of Management, Faculty of Economics, Universitas Negeri Padang, Padang, Indonesia, \\ $\checkmark$ (e-mail) megawati.me@gmail.com \\ ${ }^{3}$ Dept. of Management, Faculty of Economics, Universitas Negeri Padang, Padang, Indonesia, \\ $\square$ (e-mail) arief.isee@gmail.com
}

\begin{abstract}
This research analyzes employees' organizational commitment at public sector organizations in West Sumatra. This research used job satisfaction and perceived organizational support (POS) as antecedents of employee organizational commitment. The results of data analysis show that 1) perceived organizational support (POS) has a positive and significant effect on organizational commitment of employees at public sector organizations that were undergoing organizational change, 2) job satisfaction has a positive and significant effect on organizational commitment of employees at public sector organizations that were undergoing organizational change.
\end{abstract}

Keywords: job satisfaction, organizational commitment, perceived organizational support (POS), public sector organizations, and organizational change

\section{Introduction}

Organizational commitment of employees is one of the main issues in the field of human resource management and psychology (Rehman, et al., 2013). The organizational commitment of employees refers to the willingness of employees to strive further for the benefit of the organization, the willingness of employees to keep working on the organization and self-identification of employees with the goals and values applicable in the organization (Porter, et al., 1974).

The majority of previous research on organizational commitment tested the level of commitment to private sector organizations. Su et al. (2013) suggest that research on organizational commitment of employees to public sector organizations (government agencies) is very rare. A few previous studies have found that the employee's organizational commitment in governmental organization is lower than that of the employee's private organization. However, organizational commitment is essential, especially during organizational change, including in public sector organizations.

There is no single organization in the twenty-first century that can survive without make constant change (Cameron \& Quinn, 2006). The same case also applied to public sector organizations. During organizational change, high employee commitment is required to ensure the achievement of new and existing performance targets quickly and effectively, so that change can work (Worren et al., 1999).

To make a succeed change programs, change management requires integration of all components within the organization, and one of the most important factors is human (employee). Employees' attitudes to change have a significant effect on the behavior shown during the change (Vakola, et al., 2004). Employee commitment to the organization in the event of a change has a major effect on the success of a change.

For Indonesia itself, there is a change in public sector organizations, called bureaucracy reform, with the aim that organizations become more focused on efficiency, effectiveness and accountability (http://www.menpan.go.id/reformasi-birokrasi). Bureaucracy reform is essentially effort to make 
fundamental reforms and changes to the governance system, especially in terms of institutional aspects (organization), business process and human resources.

Various problems that resulted in the implementation of government system is not running or is not expected to run properly should be reorganized or updated. Bureaucracy reform is implemented in order to realize good governance. In other words, bureaucratic reform is a strategic step to build the employee in public organization to be more efficient and effective in carrying out the general duties of government and national development. In addition, with the very rapid progress of science, information technology and communication and strategic environment, changes demanding the government bureaucracy to be reformed and adjusted to the dynamics of community demands. Therefore, public sector must be taken steps that are fundamental, comprehensive, and systematic, so that goals and objectives that have been set can be achieved effectively and efficiently. The reform here is a gradual and continuous process of renewal, so it does not include radical and revolutionary efforts and actions.

To achieve these goals, it is vital that employees are committed to achieving organizational goal. In addition, public sector organizations should also focus on organizational commitment of employees because of its positive benefits, such as in improving employee performance, low employee turnover, reduced rejection of change, and increased productivity and overall organizational performance.

This research would like to see the level of organizational commitment of employees in public sector organizations. This research is important because so far, employees in public sector organizations have stereotypes as lazy, non-committed, and inefficient (Su et al., 2009).

\section{Organizational Commitment}

According to Porter et al. (1974) organizational commitment of employees is the willingness of employees to work more in the interests of the organization, the willingness of employees to keep working on the organization and their identification with the goals and values in the organization. High levels of organizational commitment of employees can bring benefits to the organization, among others; improving performance, low employee turnover, reduced rejection of the change program, and increasing productivity and overall organizational performance.

During this time, public sector organizations are often perceived as too large and inefficient organizations. Employees in public sector organizations are often assumed as a lazy and self-serving person (Su et al., 2009). Public sector organizations are characterized as bureaucratic with an overemphasis on formal rules, procedures, hierarchies, and formal decision-making processes, and contain political elements. Leadership in public sector organizations is tied to hierarchical organizational structures and has little independence and power in managing their subordinates. In addition, in public sector organizations, there is often clash of interests that leads to unclear organizational goals. Consequently, employees in public sector organizations will find it difficult to adapt with unclear organizational goals. It also makes it difficult for employees to assess the impact of their contribution to the organization.

This research uses organizational commitment theory of employees proposed by Su et al. (2009) that adapted measurements from Cook and Wall. In the study, Su et al. (2009) performs an analysis factor that classifies organizational commitment of employees into two dimensions, called attachments and involvement. The dimension of attachment refers to the desire of employees to keep working on their current organization and employees' pride in the organization, reflected in the way they discuss their organization to people outside the organization. The dimension of engagement refers to the extent to which employees feel part of the organization and their willingness to strive more than is expected for the organization.

Several previous studies have linked organizational commitment with employee job satisfaction (Su et al., 2013; Top \& Gider, 2013). Employees who are dissatisfied with work are often associated with low commitment. Job satisfaction is a feeling of achievement, achievement, and pride that 
employees feel about their work arrangements and are believed to be attitudes toward work. Employees who are satisfied with their work tend to behave positively in the workplace, one of which shows commitment to the organization (Top \& Gider, 2013). In addition, Su et al. (2013) also suggests that organizational commitment also influenced by perceived organizational support (POS). POS refers to the overall employee's beliefs about the extent to which the company values employees, cares about their well-being, and supports the social-emotional needs of employees by providing resources to help (Eisenberger et al., 1986). Employees who receive support from the organization are expected to demonstrate high organizational commitment (LaMastro, 1999; Beheshtifar \& Herat, 2013; Su et al., 2013).

\section{Perceived Organizational Support}

Companies usually value dedication and employee loyalty. Employees who are emotionally committed to the organization show good performance, reduced attendance, and reduced intention to leave the organization. Conversely, employees in general also pay attention to organization commitment to them. Appreciation by organizations in several areas such as approval, respect, salary and promotion, and access to information are important (Rhoades \&Eisenberger, 2002). When a person is well treated by organization, norms require them to be kind to the organization in return.

Organizational support theory (Eisenberger et al., 1986) suggests that in order to measure the organizational readiness to appreciate overwork and to achieve socio-emotional needs, employees build a general belief in the extent to which organizations value their contribution and care about their well-being. Perceived organizational support (POS) is the employee's perception of the extent to which the organization respects them and cares for them (Rhoades \& Eisenberger, 2002).

When changes happen, many uncertainties will be faced by employees (Vakola et al., 2004). Support from the organization will assist employees to face such uncertainty. Theoretically, employees who get strong organizational support will feel the need to reciprocate the good treatment of the organization with attitudes and behaviors that will benefit the organization (Eisenberger et al., 1986). This is in accordance with the social exchange theory, in which employees are expected to behave positively when they get equal treatment from the organization. Therefore, employees who receive strong organizational support are expected to have a tendency to be more committed to the organization.

\section{Hypothesis 1: Perceived Organizational Support (POS) has a positive and significant influence on organizational commitment of employees in public sector organizations that are undergoing change.}

\section{Job Satisfaction}

Job satisfaction is considered a significant indicator of organizational commitment (Top \& Gider, 2013). Increased job satisfaction is believed to strengthen organizational commitment of employees. Job satisfaction traditionally shows the satisfaction employees get from employment or employee perceptions of various aspects of their work. Another definition states that job satisfaction is a positive or negative attitude and employee perceptions of work and work environment (Pool \& Pool, 2007).

Research on job satisfaction shows that many factors affect job satisfaction, among them: job quality, employment conditions, colleagues, supervisors, administrative style, job trends, social rights, communication, personality, gender, and type of organization (public or private). Top and Gider (2013) suggests that low job satisfaction will negatively affect the organization, one of which is decreasing the level of organizational commitment of employees. This will be detrimental to the organization, including organizations that are undergoing change.

Organizations that are undergoing change require the integration of all the components that exist within the organization, and one of the most important factors is human. Human attitudes, in this 
case are employees, to change, have a significant effect on the behavior shown during the change (Vakola et al., 2004). In the study, it was argued that the employee's response to change can be seen from the most positive attitude (optimistic and interested in the success of the change program) to the most negative attitude (rejection of change). Cameron (2008) mentions that human nature will react more strongly to things that are negative. So, whenever organizations make changes, the positive goals of change will always be overshadowed by the negative responses that lead to the intention to resisting the change.

Therefore, organizations need to pay attention to employee job satisfaction, because satisfied employees tend to exhibit positive attitudes and behaviors toward the organization (Su et al., 2013). This positive attitude can be demonstrated by a high level of organizational commitment.

\section{Hypothesis 2: Job satisfaction has a positive and significant effect on organizational commitment of employees in public sector organizations that are undergoing change.}

\section{Methods}

The research began by conducting an explorative study of organizational commitment of employees to public sector organizations in West Sumatra. Then, this research examined the effect of job satisfaction and POS on employee organizational commitment. According to Cooper and Schindler (2011) the population is a collection of all elements or objects to be studied. Objects in this study were civil servants who work on organizations that are undergoing changes in the province of West Sumatra. The reason for determining the object of research because the organization undergoing a change requires a high commitment from employees to be successful. This research used purposive sampling technique, with the criterion that is set that is employee at government institution in West Sumatra.

Then the research collected data by sending out research questionnaires and going directly to several public sector organizations. Further, data were analyzed using multiple regression technique with the help of SPSS program to test the hypotheses. The regression analysis was performed to test the simultaneous impact of independent variables on the dependent variable.

\section{Results and Discussion}

Hypothesis testing used is regression analysis, with one independent variable to one or more dependent variable. Table 1 presents the results of hypothesis testing as a whole.

Table 1 Results of Hypotheses Testing

\begin{tabular}{llll}
\hline & \multicolumn{3}{l}{ Organizational Commitment } \\
\cline { 2 - 4 } & B & T & Sig. \\
\hline & & & \\
Perceived Organizational Support (POS) & 0,288 & 2,366 & $0,019^{*}$ \\
Job Satisfaction & 0,489 & 4,020 & $0,000^{*}$ \\
$\quad \mathrm{R}^{2}=0,215^{* *}$ & & & \\
\hline Source: Collected Data (2017) & & & \\
$* \mathrm{P}<0,05$ & & & \\
& &
\end{tabular}

Hypothesis 1 states that Perceived Organizational Support (POS) has a positive and significant effect on organizational commitment of employees in public sector organizations that are undergoing change. The result of hypothesis testing shows that Perceived Organizational Support (POS) has a positive and significant effect on organizational commitment of employees in public sector organizations that are undergoing change. $(B=0.288 ; \mathrm{t}=2.366 ; \mathrm{p}<0.05)$. This result supports hypothesis 1. 
Hypothesis 2 states that job satisfaction has a positive and significant effect on organizational commitment of employees in public sector organizations that are undergoing change. The higher job satisfaction in an organization, it is expected the organizational commitment of employees in public sector organizations is also higher. The result of hypothesis 2 testing shows that job satisfaction has positive and significant effect on organizational commitment of employees in public sector organization that is undergoing change $(B=0,489 ; t=4,020 ; p<0,05)$. This means that hypothesis 2 is also proven.

Organizational commitment of employees is the willingness of employees to work more in the interests of the organization, the willingness of employees to keep working on the organization and their identification of the goals and values that apply in the organization (Porter et al., 1974). High levels of organizational commitment of employees can bring benefits to the organization, among others; improving performance, low employee turnover, reduced rejection of the program, and increasing productivity and overall organizational performance.

During this time, public sector organizations are often perceived as too large and inefficient organizations. Employees in public sector organizations are often assumed as a lazy and self-serving person (Su et al., 2009). Public sector organizations are characterized as bureaucratic with an overemphasis on formal rules, procedures, hierarchies, and formal decision-making processes, and contain political elements. Leadership of public sector organizations is tied to hierarchical organizational structures and has little independence and power in managing their subordinates. In addition, in public sector organizations there is often a clash of interests that leads to unclear organizational goals. Consequently, employees in public sector organizations will find it difficult to adapt values with unclear organizational goals. It also makes it difficult for employees to assess the impact of their contribution to the organization.

Employees in public sector organizations are generally assumed to be less engaged, less loyal, and less committed to their organizations than employees in private sector organizations (Su et al., 2013). This is due to ambiguity in the organization's overly broad objectives. This situation is inversely proportional to private sector organizations, where the objectives of the organization are stated specifically and clearly.

However, public sector organizations are undergoing changes, including in Indonesia. The change of public sector organizations in Indonesia is done through bureaucratic reform. Bureaucratic reform is one of the government's efforts to achieve good governance, creating an effective, efficient, and accountable public sector organizations. Bureaucratic reform is expected to be the first step to achieve the progress of the State. Through bureaucratic reform, there is a change in the arrangement of the governance system. Bureaucracy reform is applied to public sector organizations, i.e. ministries and other government agencies.

Public sector organizations are required to serve the community quickly, accurately and professionally. Therefore, the ideals of bureaucratic reform are the realization of professional governance, legal, transparent, participatory, accountable and credible. In addition, bureaucratic reform is expected to develop bureaucratic culture and behavior based on ethics, service and public accountability and integrity. Bureaucracy reform is essentially an effort to make fundamental reforms and changes to the governance system, especially in terms of institutional aspects (organization), business process and human resources.

Bureaucracy reform in Indonesia places the importance of bureaucratic rationalization that create efficiency, effectiveness and productivity through equitable hierarchical and horizontal division of labor, measured by the ratio of volume or task load to the number of resources with formal procedures and strict supervision. Structuring central and local government organizations is based on a vision, mission and strategic objectives, policy agenda, program and performance of planned activities and directed to build a bureaucratic figure with tasks and responsibilities open and accessible. Manifestation of work procedures in intra and inter-agency relationships and between 
apparatuses with society and business world oriented to the criteria and mechanisms are impersonal directed to the implementation of excellent service. Bureaucracy reform is also a strategic step to build professional state apparatus resources, have the usefulness and professional outcomes in order to support the way of government and national development.

In line with the expansion of bureaucracy reform from the central government to local government agencies, it takes a high organizational commitment from employees, so that the change can succeed. Human attitudes, in this case are employees, to change have a significant effect on the behavior shown during the change (Vakola et al., 2004). Employee commitment to the organization in the event of a change has a major effect on the success of a change.

Based on this research, POS has positive and significant effect on organizational commitment of employees in public sector organization in West Sumatra. Organizations usually value employee dedication and loyalty. Employees who are emotionally committed to the organization show good performance, reduced attendance, and reduced intention to leave the company. Conversely, employees in general also pay attention to organizational commitment to them. Appreciated by organizations in areas such as approval, respect, salary and promotion, and access to information enhance employee commitment to organization (Rhoades \& Eisenberger, 2002).

The second hypothesis in this study found that job satisfaction has a positive and significant effect on the organizational commitment of employees in public sector organizations in West Sumatra. Job satisfaction is considered a significant indicator of organizational commitment (Top \& Gider, 2013). Increased job satisfaction is believed to strengthen organizational commitment of employees. Job satisfaction traditionally shows the satisfaction employees get from employment or employee perceptions of various aspects of their work. Another definition states that job satisfaction is a positive or negative attitude and employee perceptions of work and work environment (Pool \& Pool, 2007).

Organizations that are undergoing change require the integration of all the components that exist within the organization, and one of the most important factors is human. Human attitudes, in this case are employees, to change have a significant effect on the behavior shown during the change (Vakola et al., 2004). In the study, it was argued that the employee's response to change can be seen from the most positive attitude (optimistic and interested in the success of the change program) to the most negative attitude (rejection of change). Cameron (2008) mentions that human nature will react more strongly to things that are negative. So, whenever the organization changes, the positive goal of change will always be overshadowed by the negative response that leads to the intention of resisting change. Therefore, the organization needs to pay attention to employee job satisfaction, because satisfied employees tend to show positive attitude and behavior toward the organization Su et al., 2013). This positive attitude can be demonstrated by a high level of organizational commitment.

\section{Conclusions}

Organizational commitment of employees to public sector organizations in West Sumatra is influenced by perceived organizational support (POS) and employee job satisfaction. POS refers to the overall employee's beliefs about the extent to which the company values employees, cares about their well-being, and supports the social-emotional needs of employees by providing resources to help (Eisenberger et al., 1986). Employees who receive support from the organization are expected to demonstrate high organizational commitment (LaMastro, 1999; Beheshtifar \& Herat, 2013; Su et al., 2013).

Based on this research, POS has positive and significant effect on organizational commitment of employees in public sector organization in West Sumatra. Organizations usually value employee dedication and loyalty. Employees who are emotionally committed to the organization show good performance, reduced attendance, and reduced intention to leave the company. Conversely, employees in general also pay attention to organizational commitment to them. Employees who 
appreciated by organizations in areas such as approval, respect, salary and promotion, and access to information show high commitment towards organization (Rhoades \&Eisenberger, 2002). When a person is well treated by a company, norms require them to be kind to the company in return.

This study also found that job satisfaction has a positive and significant effect on the organizational commitment of employees in public sector organizations in West Sumatra. Job satisfaction is considered a significant indicator of organizational commitment (Top \&Gider, 2013). Increased job satisfaction is believed to strengthen organizational commitment of employees. Job satisfaction traditionally shows the satisfaction employees get from employment or employee perceptions of various aspects of their work. Another definition states that job satisfaction is a positive or negative attitude and employee perceptions of work and work environment (Pool \& Pool, 2007).

Research on job satisfaction shows that many factors affect job satisfaction, among them: job quality, employment conditions, colleagues, supervisors, administrative style, job trends, social rights, communication, personality, gender, and type of organization (public or private). Top and Gider (2013) suggests that low job satisfaction will negatively affect the organization, one of which is decreasing the level of organizational commitment of employees. This will be detrimental to the organization, including organizations that are undergoing change.

Therefore, organizations need to pay attention to employee job satisfaction, because satisfied employees tend to exhibit positive attitudes and behaviors toward the organization ( $\mathrm{Su}$ et al., 2013). This positive attitude can be demonstrated by a high level of organizational commitment.

\section{Acknowledgments}

The authors would like to express sincere gratitude to the Ministry of Research, Technology and Higher Education for funding this research.

\section{References}

Awan, M. R., \& Mahmood, K. (2010). Relationship among leadership style, organizational culture and employee commitment in university libraries. Library Management, 31(4/5), 253-266.

Bass, B. M. (1997). Does the transactional -transformational leadership paradigm transcend organizational and national boundaries? American Psychologist, 52(2), 130-139.

Beheshtifar, M., \& Herat, B. H. (2013). To promote employees' commitment via perceived organizational support. International Journal of Academic Research in Business and Social Science, 3 (1).

Bhagwagar, H. (2009). Need for workplace counseling in India. Retrieved from http:// prod.bolohealth. com/healthzones/ 21-total-health/article/165-needfor- workplace-counseling-in-india.

Bharat, B. (2008). Longer working hours for computer software engineers, India. Retrieved from http://www saching.com/Article/Longer-working-hours-for-Computer-Software-Engineers-India/1088.

Broers, C. M. (2005). Career and family: The role of social support. PhD Thesis. Griffith University.

Burke, R. J. (2002). Organizational values, job experiences and satisfaction among managerial and professional women and men: Advantage men? Women in Management Review, 17(5), 5-6.

Cameron, K. S., \& Quinn, R. (2006). Diagnosing and Changing Organizational Culture; Based on Competing Values Framework. United States of Amerika: Jossey-Bass A Wiley Imprint.

Cameron, K. S. 2008. Paradox in positive organizational change. The Journal of Applied Behavioral Science, 44 (1), 7-24.

Cooper, D. R., \& Schindler, P. S. (2011). Business Research Methods. 11 ${ }^{\text {th }}$ Edition. New York: McGrawHill.

Eisenberger, R., Huntington, R., Hutchison, S., \& Sowa, D. (1986). Perceived organizational support. Journal of Applied Psychology, 71, 500-507.

Hair, J. F., Black, W. C., Babin, B. J., \& Anderson, R. E. (2010). Multivariate Data Analysis. $7^{\text {th }}$ Edition. Singapore: Simon \& Schuster Asia Pte. Ltd. 
Hyman, J., \& J. Summers. (2004). Lacking balance. Personal Review, 33(4), 418-429.

Ismail, K., Khurram, W., Hussain, T., \& Jafri, S. K. A. (2011). Perceptions for transformational leadership, followers' psychological capital and intent to leave in Pakistan: An insight from medical and engineering sector. Interdisciplinary Journal of Research in Business, 1(8), 49-61.

Kerlinger, F. N., \& Lee, H. B. (2000). Foundations of Behavioral Research. $2^{\text {nd }}$ Edition. Harcourt College Publisher.

LaMastro, V. (1999). Commitmen and perceived organizational support. National Forum of Applied Educational Research Journal, 12(2).

Marcinkus, W. C., K. S. Whelan-Beny, \& J. R. Gordon. (2007). The relationship of social support to the work family balance and work outcomes of midlife women. Women in Management Review, 22. (2), 86-111.

Mathieu, I., \& Zajac, D. (1990). A review and meta-analysis of the antecedents, correlates, and consequences of organizational commitment. Psychological Bulletin, 108, 171-194.

Ministry of Civil Servants Empowerment. Retrieved from http://www.menpan.go.id/reformasibirokrasi.

Morgan, H. (2003). The challenges of a global marketplace. In Human resources in the 21st century, ed. M. Goldsmith, R. Gandossy, and M. Effron. New York: Wiley.

Pool, S., \& Pool, B. (2007). A management development model: Measuring organizational commitment and its impact on job satisfaction among executives in learning organization. Journal of Management Development, 26, 353-369.

Porter, L., Steers, R. M., Mowday, R. T., \& Boulian, P. V. (1974). Organizational commitment, job satisfaction, and turnover among psychiatric technicians. Journal of Applied Psychology, 59, 603609.

Rehman, K., Rehman, Z. U., Saif, N., Khan, A. S., Nawaz, A., \& Rehman, S. U. (2013). Impacts of job satisfaction on organizational commitment: a theoretical model for academicians in HEI of developing countries like Pakistan. International Journal of Academic Research in Accounting, Finance and Management Sciences, 3(1), 80-89.

Richardson, H. T., \& Vandenberg, R. J. (2005). Integrating managerial perceptions and transformational leadership into a work-unit level model of employee involvement. Journal of Organizational Behavior, 26(5): 561-589.

Rhoades, L., \& Eisenberger, R. (2002). Perceived organizational support: A Review of the literature. Journal of Applied Psychology, 87 (4), 698-714.

Scholaris, D., \& Mark, A. (2004). Work-life balance and the software workers. Human Resources Management Journal, 14(2), 54-74.

Shamir, B., House, R. J., \& Arthur, M. B. (1993). The motivational effects of charismatic leadership: A self-concept based theory. Organization Science, 4(4): 577-594.

Summer, H. C., \& Knight, P. A. (2001). How do people with different attachment styles balance work and family? A personality perspective on work-family linkage. Journal of Applied Psychology, 86 (4), 653-663.

Su, S., Baird, K., \& Blair, B. (2009). Employee Organizational commitment: The influence of cultural and organizational factors in the Australian manufacturing industry. International Journal of Human Resource Management, 20, 2494-2516.

$\mathrm{Su}, \mathrm{S} .$, Baird, K., \& Blair, B. (2013). Employee organizational commitment in the Australian public sector. International Journal of Human Resource Management, 24(2), 243-264.

Thakur, A., \& Kumar, N. (2015). The Effect of perceived organizational support, role related aspects and work involvement on work-life balance: Self efficacy as a moderator. International Journal of Scientific and Research Publications, 5(1), 2250-3153.

Top, M., \& Gider, O. (2013). Interaction of organizational commitment and job satisfaction of nurses and medical secretaries in Turkey. International Journal of Human Resource Management, 24(3), 667-683. 
Vakola, M., Tsaousis, I., \& Nikolaou, I. (2004). The role of emotional intelligence and personality variables on attitudes toward organizational change. Journal of Managerial Psychology, 19(2): 88110.

Wayne, S. J., Shore, L. M., \& Liden, R. C. (1997). Perceived organizational support and leader-member exchange: A social exchange perspective. Academy of Management Journal, 40, 82-111.

Worren, N., Ruddle, K., \& Moore, K. (1999). From organizational development to change management: The emergence of a new profession. Journal of Applied Behavioral Science, 353, 273286.

Wu, C., Neubert, M. J., \& Yi, X. (2007). Transformational leadership, cohesion perception and employee cynicism about organizational change. The Journal of Applied Behavioral Science, 43(3), 327-351. 